\section{Disease research}

\section{Tropics still a low priority}

Washington

THE small amount of money spent by the United States on tropical disease research ( $\$ 100$ million of an annual biomedical research budget of $\$ 4,000$ million) reflects policy choices and not the lack of promising avenues of research, according to an Office of Technical Assessment (OTA) report published last week. Much of the recent progress has been made by small but "highly motivated" groups of researchers. Biotechnology and new techniques in immunology, combined with traditional parasitology and infectious diseases research, make the possibilities for alleviating the suffering caused by tropical diseases greater than ever before, OTA says.

The report stresses the "enormous potential" of genetically engineered vaccines, although the first of these, the malaria vaccine, is unlikely to be generally available for $5-10$ years. No vaccines yet exist for human parasitic diseases and there are only a few for viral and bacterial diseases; biotechnology will allow safe and effective vaccines to be developed for many of these diseases.

OTA says that insecticides are still useful in disease control, although no single technology is likely to be able to control most vectors of disease. Integrated pest management, a relatively new approach that combines biological and chemical methods, has not had time to prove itself, but OTA says that long-term solutions may be provided by these methods.

OTA's problem is how to encourage research in an area that has poor commercial rewards. It cites some successes, for example, praziquantel, a drug that has revolutionized schistosomiasis treatment but is expensive; oral rehydration therapy for diarrhoeal diseases; and ribavarin, a drug that seems to be effective against Lassa fever in West Africa. But federal science budgets are tight and have other priorities; pharmaceutical companies are reluctant to invest in the development of drugs of no commercial value.

One suggestion made by OTA is that tropical disease drugs be classified as "orphan" drugs, which would provide certain statutory benefits to companies developing them. The government could also guarantee the purchase of products and assistance in field trials, or authorize funds to establish a nonprofit organization to undertake research until the products are attractive enough for the private sector to take over. In the short term, however, the report suggests that a special congressional appropriations hearing be held to take evidence from those organizations that support tropical disease research and to identify areas where effort could be increased. An increase in federal funding or the removal of statutory limitations on the amount of research supported by the Department of Health and Human Services might result from such an investigation.

For the 5 million US citizens estimated to be at risk of contracting tropical diseases, many of them in the armed forces, and the millions of people in the developing countries who die as a result of these diseases each year, there is no immediate chance that the United States will channel more resources towards research in this field.

Maxine Clarke

"Status of Biomedical Research and Related Technology for Tropical Diseases" (OTA-H 258) is available from the US Government Printing Office, Washington, DC, price \$11.00.

\title{
The world's legumes go on-line
}

WITH the inauguration of an ambitious new database and information service, anybody with access to a personal computer should be able to tune in to the world's expertise on the 17,000 species in the Leguminosae family.

The legume family includes pulses such as peas, beans, lentils and soya, forages such as clover and vetches, sources of insecticides and haemagglutinins, and even trees for timber production. To handle the data generated by such diversity, the "ILDIS" database - the International Legume Database and Information Service - was established at a workshop held at Southampton University last month. The project combines the data collected by 16 research groups, with major contributions (in funds and facilities) from the Royal Botanic Gardens Kew, Missouri Botanical Garden St Louis, the University of Southampton, Biosciences Information Service
(BIOSIS) of Philadelphia and the UK Science and Engineering Research Council.

The database is to include details of the taxonomy and chemistry of each plant, distribution, potential agricultural uses and conservation status. The information is to be available online from Philadelphia in the United States and from York in the United Kingdom. To ensure a wide availability for the ILDIS data - to the arid and humid tropical areas where legumes are the major crop for instance - it will also be available on standardized computer software that can be provided by post.

For more information on ILDIS, potential users and contributors should contact the project coordinator, Dr Frank Bisby at the Biology Department, Southampton University, Southampton S09 5NH, UK. The next challenge will be the largest group of plants - the Triticalae, including the grasses and cereals. Charles Wenz
Soviet psychiatry Aiming for rehabilitation?

THE Soviet All-Union Society of Neurologists and Psychiatrists seems to be angling for readmission to the World Psychiatric Association (WPA). The first ever congress of psychiatrists from socialist countries, held in Moscow last month, was used by several Soviet psychiatrists and their Comecon colleagues to drop appropriate hints. The Soviet Union resigned from WPA in January 1983, preempting a motion of exclusion tabled for the World Psychiatric Congress in Vienna the following July. Subsequently, the Cuban, Bulgarian and Czechoslovak associations resigned also.

The motion of expulsion was a reaction to a growing body of evidence on the Soviet misuse of psychiatric methods and psychotropic drugs for the repression of political dissidents and religious believers. Last month's Moscow congress was used by the participants to deny these reports. WPA was said to have launched a "campaign of slander" against the Soviet Union and its allies. According to a Czech psychiatrist, Dr Jozef Pogady, "manifestations of disease which are clear to specialists were withheld, distorted and presented in the light needed by the organizers of the campaign" to create an "appalling myth". He was, presumably, referring to "creeping schizophrenia", a disease unrecognized in the West, but which, according to its "discoverer", Professor Aleksandr Snezhnevskii, exhibits no symptoms apart from political or religious or nonconformity. In view of this major difference in outlook, dialogue between the two psychiatric "camps" would seem futile, and the Moscow congress may well turn out to be a first step in establishing a Socialist Psychiatric Association.

For the moment, however, the Soviet psychiatrists seem more keen to reastablish their reputation with WPA than to set up an alternative. Accordingly, during the recent congress, the deputy director of the Serbskii All-Union Research Institute for General and Forensic Psychiatry (a source of many diagnoses of "creeping schizophrenia"), stated that Soviet psychiatry stands "in defence of human rights", while Dr Johannes Neumann of the German Democratic Republic claimed that since the 1983 World Congress, WPA's leadership had become "more fair and objective", and that an increasing number of member countries of WPA rejected the allegations of Soviet psychiatric abuse.

Although normally considered a hardline country, East Germany did not withdraw from WPA in 1983 and Dr Neumann is now a WPA vice-president. He would therefore be an obvious intermediary if the Soviet Union were to seek readmission to WPA.

Vera Rich 